\title{
Location image "halo effect" on museum image: an exploratory survey of British Museum visitors
}

\author{
ALFONSO SIANO** MARIO SIGLIOCCOLO*** \\ MADDALENA DELLA VOLPE ${ }^{* * * *}$ FELICE ADDEO*****
}

\begin{abstract}
Purpose of the paper: This paper explores the museum image formation process, with particular focus on the case of the British Museum in London. The research aims to analyze whether, among the different variables traditionally identified by literature on this issue (motivations, expectations, satisfaction, sources of information etc.), it is possible to identify a "halo effect" of London's image which influences British Museum visitors' image formation

Methodology: Considering the exploratory nature of the study, a non-probabilistic sampling procedure was chosen. Data were collected through a structured questionnaire, and interviewees were selected through a non-probability sampling procedure. Data analysis involved multivariate regression, performed through SPSS software

Findings: The collected data provided a preliminary response to the main research question posed by this paper: could the halo effect of London's image play a role in developing the image visitors have of the British Museum?

Research limits: Due to the sample size of visitors, the research has a mainly exploratory value and intends to represent a pilot study on this issue

Although the views and ideas expressed in this paper are those of Alfonso Siano, Mario Siglioccolo, Maddalena Della Volpe, and Felice Addeo, the sections "Introduction" and "Conclusions" are attributed to Alfonso Siano, the sections "Literature review" and "Implications for museum and place marketing" are attributed to Mario Siglioccolo, the sections "Aim of the paper and research hypothesis" and "Research limits and indications for further research" are attributed to Maddalena della Volpe, and the sections "Methodology", "Research design", "Concept map", "Sampling and data collection", and "Data analysis" are attributed to Felice Addeo.

** $\quad$ Ordinario di Economia e Gestione delle Imprese - Università degli Studi di Salerno e-mail: sianoalf@unisa.it

*** Docente a contratto di Marketing dei Beni Culturali e Advertising and media planning - Università degli Studi di Salerno

e-mail: msiglioccolo@hotmail.it

**** $\quad$ Associato di Economia e Gestione delle Imprese - Università Suor Orsola Benincasa di Napoli

e-mail: maddalena.dellavolpe@ unisob.na.it

***** Ricercatore di Sociologia Generale - Università degli Studi di Salerno e-mail: faddeo@unisa.it
\end{abstract}


Practical implications: The existence of a halo effect on the image of London's British Museum is a factor to be considered for the identification of museum marketing strategies developed specifically for visitors who appear sensitive to this effect.

Originality of the study: Compared to the literature so far produced on museum marketing, this paper differs in focusing on the relationship between museum image and its location

Key words: halo effect; London image; British Museum image; exploratory survey

\section{Introduction}

In recent years, the significance of analyzing museum visitors' perceptions through field surveys has been increasingly asserted (Yucelt, 2000; Reussner, 2003). However, although the centrality of research on visitors is now widely accepted in both academic and practical terms, literature has so far neglected the relationship between the appeal of museums and the attractiveness of the place where they are located.

This paper explores the connection between museum and location, and aims to identify a "halo effect" of a location's image which influences visitors' museum image formation, with particular reference to the case of the British Museum in London.

Although the halo effect is one of the oldest and most widely known psychological phenomena (Nisbett and DeCamp Wilson, 1977), surprisingly little is known about its application to museums and their locations. This seems such a lacuna, considering that museums are location-based institutions, and they may not be separated from their territorial context. Museums succeed not only as economic development engines, but also as attractions within tourist destinations, as they are deeply rooted in their territory of reference, and this is one of their main features.

The halo effect related to the country of origin may be defined as any influence that the country of manufacture has on a consumer's positive or negative perception of a product (Cateora and Graham, 1999). Studies in industrial purchasing have found the halo effect to be a salient cue of quality in buyers' perception, and it has been recognized that inferences may (correctly or incorrectly) alter the judgement of consumers (Fishbein and Ajzen, 1975). For example, a person whose bias suggests that German cars convey the idea of safety and are durable, might infer that since an Audi is a German car, an Audi is a safe and durable car.

Consumer behaviour can be seriously impacted by the halo effect in many distinct ways: buyers may simply use the country of origin as one of the many attributes employed to engage in product evaluation (Johansson et al., 1985), or the country of origin may create a halo effect whereby consumers' attention and evaluation of other product dimensions are affected (Han, 1989). Various studies reveal that a product's country of origin can affect its evaluation, and, like price, may serve as a proxy variable when information is lacking (Bilkey and Nes, 1982; Huber and McCann, 1982). The issue considered in this study assumes even more 
importance considering that image has a direct effect on visitor satisfaction (Chon, 1990; Pearce, 1997).

As shown in the previous examples, outside variables may have inferential effects on product beliefs. With specific regard to museums and the effect of their country of location, little research seems to have been carried out.

\section{Literature review}

In modern times, museums have taken on the functions of collection, research and exhibition, as well as education and recreation, and have gradually acquired visitor-based roles instead of museum-based roles. Thus, the need for visitor studies has emerged (Weil, 2000), and obtained full recognition both from an academic and an operational point of view (Solima, 1999). This has led museums to conduct research on visitors, acquiring knowledge about them and applying it to planning and decision-making, in order to offer exhibitions and services that are suitable for visitors (Liu, 2008). The growing interest of the scientific community in this area of analysis has also been accompanied by a progressive increase in attention from museum staff members.

Although museums in recent years have given serious consideration to attracting tourists, there is very little understanding of the image formation process of a museum (Gil and Ritchie, 2009; Harrison, 1997) and its relationship with the place where the museum is located. This lack is due in part to the fact that museums and their locations have been regarded as two separate issues for most of the past century, and museums have been considered as organizations where marketing concepts could be applied regardless of the place where they are located. Although a symbiotic relationship between museums and the communities they serve has been previously described (DiMaggio, 1991; Janes, 1997; 1999), no contribution has focused explicitly on the link between location image and its effect on museum image.

Image is of great importance to the tourist industry and has been extensively analyzed in tourism literature (Echtner and Ritchie, 1991). In conceptual terms, image is an overall mental picture formed from the mass of information available to the visitor, both about the specific museum and about museums in general (Vaughan, 2001).

The first reported work in the literature concerning museum image stressed that residents tend to have positive images of a local museum (Rosenberg et al., 1960). Recent interesting studies analyze, among other things, the image of a destination that tourists have prior to visiting a local museum (Harrison, 1997), the nature of the images residents have of a museum, and the relationship between previous experience and image (Vaughan, 2001).

Although there is a tendency to define image by using the perceptual or cognitive approach, recent studies tend to view image as a combined concept that results from both the consumer's logical interpretation (cognitive) and emotional (affective) 
interpretation of the destination. These two elements of image form an overall or holistic image that may reflect either a positive or a negative evaluation of the product or service (Kawashima, 1999).

A differentiation between the cognitive and affective evaluations leads to a greater understanding of how an individual's values affect image formation: while the cognitive component reflects knowledge of the product's features, the affective component refers to the emotional response to the product. The importance of the emotional component of image is such that it may exercise a greater influence on visitors' behaviour than the attributes that constitute the cognitive component of image (Russell and Snodgrass, 1987).

The formation of museum image is an ongoing process (Vaughan, 2001), and although a museum's image is difficult to change (Kawashima, 1999), a review of the literature on tourist image reveals the existence of a set of factors that influence the process of image formation. It has been observed that sources of information and visitor motivations are key elements in that process (Baloglu and McCleary, 1999; Stern and Krakover, 1993).

The information sources, also called image formation agents (Gartner, 1993) and stimulus factors (Baloglu and McCleary, 1999), are the forces that influence the formation of perceptions and evaluations. The different sources of information that affect image formation may be primary (previous experience of visiting a museum), or secondary information acquired without firsthand visitation to a museum (e.g. advertising, information about the company diffused by mass media, word-of-mouth etc.) (Phelps, 1986). Motivations, or reasons for visiting museums, are one of the most popular research topics for museums (Kawashima, 1999).

Motivations are internal factors defined as the benefits and advantages sought by individuals when they decide to visit a museum (Um and Crompton, 1992). A number of scholars have identified a variety of motivations for visiting museums, such as to be entertained, to learn, because they are on holiday, to visit a particular exhibition, to be with people and enjoy social interaction, to do something worthwhile, to feel comfortable with the surroundings, to enjoy the challenge of a new or unusual experience, to have a learning opportunity, and to participate actively (Jansen-Verbeke and Van Rekom, 1996; Kotler and Kotler, 2001; Prentice et al., 1998). Motivations are internal factors defined as the benefits and advantages sought by individuals when they decide to visit a museum, and as such, they constitute a factor that influences the processes of image formation.

Although these studies have the merit of identifying the variables determining museum image, none of the contributions on museum image formation have analyzed the existence and the relevance of a location halo effect on museum visitors' image formation process to date. Research on halo errors in rating can be traced back to the early part of this century (Thorndike, 1920; Wells, 1907).

Such a phenomenon could best be described as a deduction from an implicit personality theory holding that "nice people tend to have nice attributes and less nice people have less nice attributes". 
Thorndike (1920) phrased the term "halo effect" to describe the tendency of a judge to rate individual traits according to the rater's general impression of the object that is being rated. Subsequently, the ratings of single traits may be either systematically inflated or deflated, depending on whether the rater's overall impression or attitude toward the object is positive or negative. For instance, if the overall attitude is positive, the inflated ratings of individual attributes may mislead the user of the rating information to falsely conclude that the object of the evaluation is more superior in all attributes than is actually the case.

Although there are a number of different conceptual and operational definitions of halo effect (Balzer and Sulsky, 1992; Saal et al., 1980), the occurrence of halo effect seems to be common (Cascio, 1991; Feldman, 1986) and ubiquitous (Cooper, 1981). This consideration leads to an analysis on its pertinence to museums, which are closely linked to their locations.

\section{Aim of the paper and research hypothesis}

The aim of the exploratory survey in this paper is to examine and explore the role of location image in the museum image formation process. Put specifically, the research analyzes whether, between the variables traditionally identified by literature on this issue (motivations, expectations, satisfaction, sources of information etc.) (Kim et al., 1996; Rekom, 1994; Thyne, 2001), it is possible to identify a "halo effect" of a location's image which influences visitors' museum image formation. In particular, the case of the image formation process of the visitors of the British Museum was considered for the aim of this study.

The choice of the British Museum is justified by its ability to attract tourist flows representing different countries and cultures. In addition, the image of London to be measured in this study provides a good first impression, as it refers to one of the most visited cities in the world.

Based on the conceptual and empirical perspectives gained from the literature, the hypotheses proposed in this study are the following (see figure 1):

- location image may influence museum image formation process (H1);

- location image is positively correlated to museum image (H2):

- the higher the values of all the independent variables (location image, visitor satisfaction, expectations etc.) the more the visitors' perception of a museum shifts toward a positive image (H3).

The next sections focus on the methodology used for this study, and the implications for museum marketing activities to be developed, taking into account the role of location image halo effect in the museum image formation process. 
Fig. 1: The proposed framework: the factors determining museum image and the potential role of location image halo effect

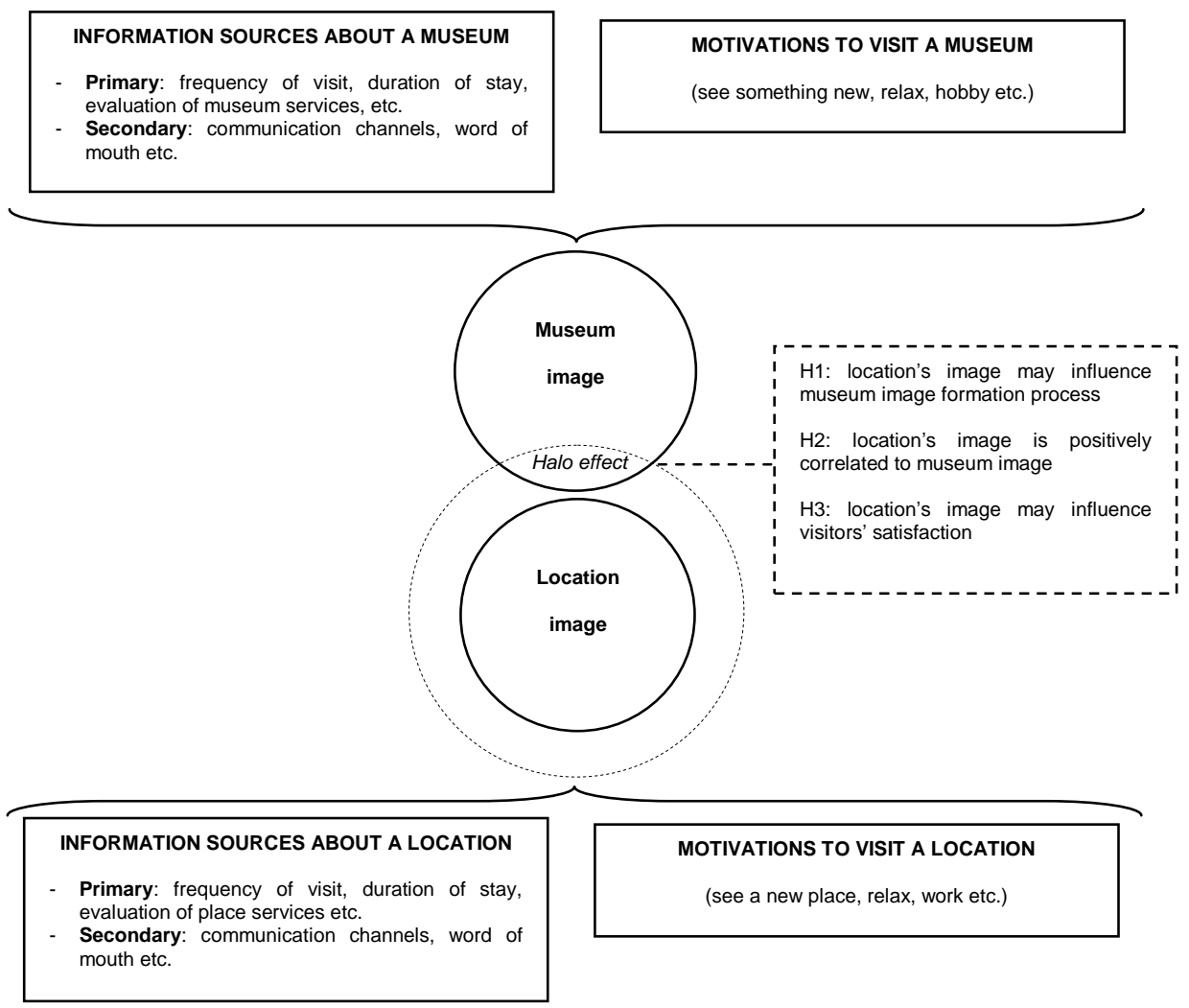

Source: our elaboration

\section{Methodology}

\subsection{Research design}

The theoretical framework presented in the previous pages inspired exploratory empirical research on the British Museum, required in order to check the effectiveness of the hypotheses. The main research goal was to explore the connection between the museum and its location, hypothesizing the presence of the "halo effect" of the latter on the former. Put specifically, the main hypothesis is that, among other variables, the perceived image of London may positively influence the perceived image of the British Museum.

Stating these premises, and considering the research goal and its methodological implications, a quantitative approach was adopted: data were collected through a 
structured questionnaire administered to the visitors of the British Museum, interviewees were selected through a non-probability sampling procedure, and data analysis, performed through SPSS software, involved multivariate regression.

\subsection{Concept Map}

The first research step was the choice of the conceptual dimensions considered by the research team to be at the core of the empirical research: starting from a concept map representing research dimensions and, for each of them, the indicators to be operationally integrated into the items of our questionnaire ${ }^{1}$.

As shown in figure 2, the main research dimensions are:

- socio-graphic (gender, age, qualification, nationality, residence, occupation, annual income);

- museum: sub-articulated Experience, Evaluation, Satisfaction;

- London: sub-articulated Experience, Evaluation, Satisfaction;

- museum vs. London: to evaluate if a visitor is driven by the British Museum or London in his decision to visit the Museum.

Table 1 shows the indicators chosen for each dimension, their operational definition and their measurement. The indicators shown in table 1 were operationally defined in the items of a structured questionnaire according to the chosen type of measurement.

\subsection{Sampling and data collection}

The unit of analysis is made up of British Museum visitors. Considering the exploratory nature of the research, a non-probabilistic sampling procedure was chosen, so interviewees were randomly selected among the people who visited the Museum during the month of October 2009. Data were collected by administering the structured questionnaire to tourists: the final sample is composed of 120 individuals.

1 Concept maps may be defined as a taxonomic structure in which all relevant dimensions and concepts of a theoretical research model are presented and related. Concept maps are helpful to researchers in clarifying, according to their research goals, what and how many research dimensions should be considered to create a fruitful research track. Operationally, it could also be helpful to identify measurable concepts and possible relations among variables (Marradi, 2007, pp. 203-204). Ovals in figure 2 represent conceptual dimensions that are too general to be operationally defined, while the indicators that were empirically observed are shown in the boxes. 
Fig. 2: Concept Map: London's image halo effect on British Museum visitors

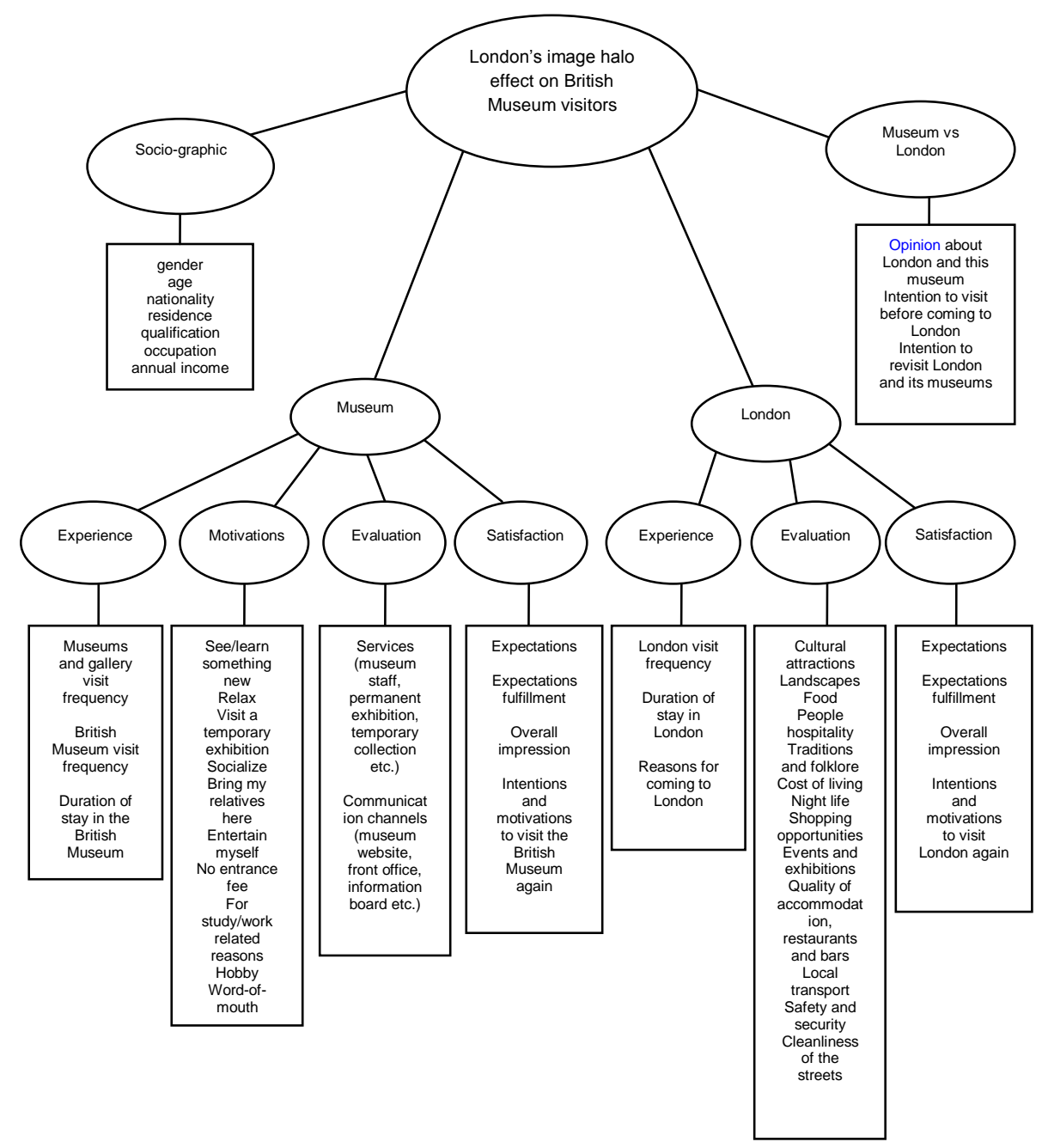

Source: our elaboration

\subsection{Data analysis}

Data analysis was performed in four sequential steps: first, data quality control procedures were carried out to prevent errors in data analysis; then a univariate analysis (mean, standard deviation etc.) was performed to have a general overview of the distribution of the variables and to obtain essential information for the next research step: building indexes to synthesize a set of variables. Thus, combining respondents' answers to two batteries of items measuring different aspects under the 
evaluation dimension, two indexes were created: the first measuring satisfaction with the British Museum communication (ComSat), the second measuring satisfaction with the core services of the British Museum (CoSeSat).

Finally, a multiple regression analysis - a multivariate technique through which one can analyze the relationship between a dependent variable and a set of independent variables (Ho, 2006, p. 246) - was carried out in order to test main research. In our model, the dependent variable is British Museum image, which was operationally defined through an eleven point Cantril Scale aimed at measuring tourists' perception of the museum's image. Independent variables are: overall impression of London (i.e. the "halo effect"); expectations prior to the visit to the British Museum (both variables were measured with an eleven point Cantril Scale); overall Communication Satisfaction Index (ComSat) and overall Core Services Satisfaction Index (CoSeSat). Table 2 shows the results of this multiple regression analysis.

Tab. 1: Research dimensions, Indicators' operational definition and measurement

\begin{tabular}{|c|c|c|c|c|}
\hline $\begin{array}{c}\text { Research } \\
\text { dimensions }\end{array}$ & \multicolumn{2}{|c|}{ Variables } & Operational definition & Measurement \\
\hline \multirow{7}{*}{$\begin{array}{l}\text { Socio- } \\
\text { graphic }\end{array}$} & \multicolumn{2}{|l|}{ gender } & Sex & Dichotomy \\
\hline & \multicolumn{2}{|l|}{ age } & Years & Open question \\
\hline & \multicolumn{2}{|l|}{ qualification } & $\begin{array}{l}\text { Highest qualification obtained by } \\
\text { interviewees }\end{array}$ & \\
\hline & \multicolumn{2}{|l|}{ nationality } & Interviewees' Nationality & \\
\hline & \multicolumn{2}{|l|}{ residence } & City in which an interviewee lives & IViurtinomial \\
\hline & \multicolumn{2}{|l|}{$\begin{array}{l}\text { occupation } \\
\text { annual income }\end{array}$} & Current occupation of interviewees & \\
\hline & \multicolumn{2}{|l|}{ annual income } & Current annual income of interviewees & \\
\hline \multicolumn{5}{|l|}{ Museum } \\
\hline \multirow{3}{*}{ Experience } & \multicolumn{2}{|c|}{ Museum/Galleries visit frequency } & $\begin{array}{l}\text { How often do you go to museums and } \\
\text { galleries? }\end{array}$ & \\
\hline & \multicolumn{2}{|c|}{ British Museum visit frequency } & Your visit to this museum was & Multınomial \\
\hline & \multicolumn{2}{|c|}{ Duration of stay in British Museum } & How long were you in this museum? & \\
\hline \multirow{10}{*}{ Evaluation } & Services & Communication & \multirow{10}{*}{ Satisfaction level with each item } & \multirow{10}{*}{$\begin{array}{l}\text { 1-10 Cantril } \\
\text { Scale }\end{array}$} \\
\hline & Museum staff & Museum Website & & \\
\hline & $\begin{array}{l}\text { Permanent } \\
\text { collections }\end{array}$ & Front office & & \\
\hline & $\begin{array}{l}\text { Temporary } \\
\text { exhibitions }\end{array}$ & General Guides & & \\
\hline & Accessibility & Tourist Guides & & \\
\hline & $\begin{array}{l}\text { Museum } \\
\text { Catering }\end{array}$ & Museum Guides & & \\
\hline & $\begin{array}{l}\text { Museum } \\
\text { Shops }\end{array}$ & $\begin{array}{l}\text { Audio/Multimedia } \\
\text { Guides }\end{array}$ & & \\
\hline & $\begin{array}{l}\text { Museum } \\
\text { Toilets } \\
\end{array}$ & Descriptions & & \\
\hline & Other facilities & Brochures & & \\
\hline & & Signage & & \\
\hline \multirow{5}{*}{ Satisfaction } & & \multirow{3}{*}{ Satisfaction level with each item } & \multirow{3}{*}{$\begin{array}{l}\text { 1-10 Cantril } \\
\text { Scale }\end{array}$} \\
\hline & \multicolumn{2}{|c|}{$\begin{array}{l}\text { Expectations } \\
\text { Expectations fulfilment }\end{array}$} & & \\
\hline & \multicolumn{2}{|c|}{ Overall Impression } & & \\
\hline & \multicolumn{2}{|c|}{$\begin{array}{l}\text { Intention to visit the British Museum } \\
\text { again }\end{array}$} & $\begin{array}{l}\text { Are you going to visit the British Museum } \\
\text { again? }\end{array}$ & Multinomial \\
\hline & \multicolumn{2}{|c|}{$\begin{array}{l}\text { Motivations to visit the British } \\
\text { Museum again }\end{array}$} & $\begin{array}{c}\text { You going to visit British Museum again } \\
\text { because ... }\end{array}$ & Multinomial \\
\hline \multicolumn{5}{|l|}{ London } \\
\hline \multirow{3}{*}{ Experience } & \multicolumn{2}{|c|}{ London visit frequency } & $\begin{array}{l}\text { How many times have you been to } \\
\text { London? }\end{array}$ & \\
\hline & \multicolumn{2}{|c|}{ Duration of stay in London } & How long are you staying in London? & Multinomial \\
\hline & \multicolumn{2}{|c|}{ Reasons for coming to London } & Your reasons for coming to London & \\
\hline
\end{tabular}




\begin{tabular}{|c|c|c|c|}
\hline \multirow{14}{*}{ Evaluation } & Cultural attractions & \multirow{14}{*}{ Satisfaction level with each item } & \multirow{14}{*}{$\begin{array}{l}\text { 1-10 Cantril } \\
\text { Scale }\end{array}$} \\
\hline & Landscapes & & \\
\hline & Food & & \\
\hline & People's hospitality & & \\
\hline & Traditions and folklore & & \\
\hline & Cost of living & & \\
\hline & Night life & & \\
\hline & Shopping opportunities & & \\
\hline & Specific events and exhibitions & & \\
\hline & Quality of restaurants and bars & & \\
\hline & Quality of accommodation & & \\
\hline & Local transport facilities & & \\
\hline & Safety and Security & & \\
\hline & Cleanliness of the streets & & \\
\hline \multirow{5}{*}{ Satisfaction } & Expectations & \multirow{3}{*}{ Satisfaction level with each item } & \multirow{3}{*}{$\begin{array}{l}\text { 1-10 Cantril } \\
\text { Scale }\end{array}$} \\
\hline & Expectations fulfilment & & \\
\hline & Overall Impression & & \\
\hline & Intention to visit London again & Are you going to visit London again? & Multinomial \\
\hline & Motivations to visit London again & You going to visit London again because & Multinomial \\
\hline \multicolumn{4}{|l|}{$\begin{array}{l}\text { Museum vs. } \\
\text { London }\end{array}$} \\
\hline \multirow{5}{*}{$\begin{array}{l}\text { Museum vs. } \\
\text { London } \\
\text { propensity }\end{array}$} & \multicolumn{2}{|c|}{4 items evaluating if visitors were mainly driven by British Museum or London } & \multirow{5}{*}{ Multinomial } \\
\hline & Opinion on London and this museum & $\begin{array}{l}\text { Which of these sentences best } \\
\text { describes your point of view about } \\
\text { London and this museum }\end{array}$ & \\
\hline & $\begin{array}{l}\text { Opinion on the location of the } \\
\text { museum }\end{array}$ & $\begin{array}{l}\text { Which of these sentences better } \\
\text { correspond to your point of view about } \\
\text { the location of the museum }\end{array}$ & \\
\hline & $\begin{array}{l}\text { Intentions before coming to London in } \\
\text { relation to the British Museum }\end{array}$ & $\begin{array}{l}\text { Which of these sentences best } \\
\text { describes your intention to revisit } \\
\text { London and its museums }\end{array}$ & \\
\hline & $\begin{array}{l}\text { Intention to revisit London and its } \\
\text { museums }\end{array}$ & $\begin{array}{l}\text { Which of these sentences best } \\
\text { describes your intention }\end{array}$ & \\
\hline
\end{tabular}

Source: our elaboration

Tab. 2: Multiple Regression Analysis: Model Summary and Coefficients

Model Summary

\begin{tabular}{|r|r|r|r|}
\hline R & R Square & $\begin{array}{c}\text { Adjusted R } \\
\text { Square }\end{array}$ & $\begin{array}{c}\text { Std. Error of } \\
\text { the Estimate }\end{array}$ \\
\hline, 788 &, 621 &, 602 &, 952 \\
\hline
\end{tabular}

\section{Coefficients}

\begin{tabular}{|c|c|c|c|c|c|}
\hline \multirow[t]{2}{*}{ Model } & \multicolumn{2}{|c|}{$\begin{array}{l}\text { Unstandardized } \\
\text { Coefficients }\end{array}$} & \multirow{2}{*}{$\begin{array}{c}\text { Standardized } \\
\text { Coefficients }\end{array}$} & \multirow[t]{2}{*}{$t$} & \multirow[t]{2}{*}{ Sig. } \\
\hline & B & Std. Error & & & \\
\hline (Constant) & 1,084 & ,777 & &,- 417 & 167 \\
\hline CoSeSat & ,426 &, 083 & ,447 &,- 417 &, 000 \\
\hline Expectations & ,217 & 073 & ,238 & 3,140 &, 004 \\
\hline Halo effect & ,244 &, 085 & ,221 & 4,754 &, 005 \\
\hline ComSat & ,205 &, 115 &, 136 & 2,211 &, 080 \\
\hline
\end{tabular}

Source: our elaboration 
According to the reported value of R-square, the set of independent variables explains more than $60 \%$ of the variance of the dependent variable; in other words, as $\mathrm{R}$ squared quantifies the goodness of fit, it could be said that the model fits the data (H1 and $\mathrm{H} 2$ confirmed).

The direction and the size of the beta weight coefficients shed light on the nature of these relationships: Beta coefficients' directions are all positive: this means that the higher the values of all the independent variables, the more tourists' perception of British Museum shifts toward a positive image (H3 confirmed). Considering the size of beta weight, CoSeSat has the strongest influence $(447)$ on British Museum image, followed by Expectations $(, 238)$ and the halo effect $(, 221)$, while ComSat turns out not to be statistically significant.

\section{Implications for museum and place marketing}

Efforts to measure visitors' perceptions of service performance and levels of satisfaction are made in the belief that they enable managers to monitor how well they are performing and to identify where adjustments need to be made in order to raise the quality of the offer and experience that visitors receive (Tomas et al., 2003). The results of the research encourage a consideration of museums and their location as a "global product", which comprises museum and place services. Museum visitors (be they foreign or resident) now seek a total experience, including leisure, culture, education and social interaction.

These considerations lead to combining two complementary approaches museum marketing and place marketing - in the management of museum and location image. Recent developments in contributions on management show that the assessment of esteem and credibility, socially shared, based on the past actions and performance of an organization (especially in terms of ability to satisfy the expectations of stakeholder groups) is increasingly critical for engendering competitive advantage (Bennett and Kottasz, 2000; Fombrun and van Riel, 2004). A similar consideration also applies to location: because of its strategic value, developing a good location image is a fundamental objective of tourism and vacation/destination marketing and of place marketing and communication activities, as it ensures several positive effects including, among others, the attraction of potential travellers, tourists and investors and their loyalty (Siano et al., 2008; Siano et al., 2009; Confetto et al., 2009).

Hence, what may British Museum managers do to benefit from the positive image of their location? The British Museum is located in London, along with the most visited museums in U.K. (twelve out of the twenty top museums); the high competitiveness of this location represents a good starting point for the valorisation of the image of the analysed museum. These museums benefit from being located in these favourable conditions: in order to take advantage of the positive halo effect of their location, museums could enhance their brand awareness by stipulating partnership and co-marketing activities with local institutions and government. 
Among others, the transfer of positive association may be developed by matching the brand of the museum with that of the location (co-branding) (Blackett and Boad, 1999; Kumar, 2005; Shawn, 2000). The technique of co-branding involves cooperation and coordination between museums and government authorities and agencies in order to enhance the value both of the museum brand and the location brand (Dredge and Jenkins 2003; Thomas and Long 2000).

Cross-sector collaboration is another marketing opportunity: managers might collaborate with local governments, providing recommendations to enhance place offers, and encourage local tourist organizations (hotels, bars, restaurants etc.) to promote their services and become jointly involved in place marketing activities.

Cooperative advertising between museum and their location is another interactive action that may easily be developed. This activity, which usually involves two members in a manufacturer-retailer supply chain (Li et al., 2002; Yue et al., 2006), may be used by museums and local institutions to advertise their activities together, with large savings in investment in communication.

The association of brands may also be made online by means of cooperative eadvertising activities and an online virtual museum: a virtual museum refers to a collection of digitally recorded images, sound files, text documents, and other data of historical, scientific, or cultural interest that can be accessed through electronic media (Bernier, 2002). Virtual on-line exhibitions may act as a promoter of real museums and simultaneously promote the location.

Museums and their locations can offer mutual support in terms of marketing (Siano et al., 2010; Siano and Siglioccolo, 2008); the full exploitation of this opportunity depends, however, on the ability of museum managers to cooperate with local governments and agencies for the coordination of promotional programs and activities (such as tour operators) (Siglioccolo et al., 2009). Thus, both museum management and destination competitiveness can be seen as part of a coherent and likely synergistic whole, and marketing cooperation seems to be mandatory.

\section{Research limits, and indications for further research}

It seemed appropriate to dedicate a section to the limits of the study. Due to the sample size of visitors, the research has a mainly exploratory value, and intends to represent a pilot study on this issue. The findings are limited to unidirectional influences among the variables in the model (a recursive causal model) because reciprocal relationships among the variables have not been studied. Future research might develop and test a model with bidirectional influences between variables. Findings are also limited to the British Museum, located in London; future research might extend the sample size of visitors analyzed, and could be carried out to validate the findings of this study in different locations to assess the validity of the findings, or with relation to clusters of museums. Furthermore, the approaching departure of the visitors from the British Museum could have invalidated the judgement of the respondents (with answers given immediately, or without thinking 
too much due to tiredness after visiting the museum, exhaustion from walking too much etc.). The use of mixed-method approaches, with the integration of a qualitative approach, could also be useful to improve the findings of this research.

The findings are also limited to the variables selected for the study. There may be other factors influencing the image formation process of a museum (e.g., psychographic variables, such as values, attitude towards the artwork etc.); future research might expand the model by integrating such variables with others linked to other museums to be surveyed.

Future contributions to this topic could identify and examine the barriers to the implementation of the suggestions proposed here, which may focus not only on marketing, but also involve the use of internal (and entrenched) policies, practices and organisational culture. Further primary research on visitors' behaviour could explain in detail any causal links between the popularity of museums and their particular locations, and the features and attributes of London's image that visitors assign to the British Museum through halo effect.

\section{Conclusions}

A critical examination of previous museum image studies has revealed that researchers have not been successful in completely conceptualising and operationalising museum image. By providing a framework for the measurement of museum image, this paper hopes to draw attention to the need to address all components of museum image, both in future research and in managerial decision making.

This paper endeavoured to provide a more thorough understanding of the concept of museum image and the variables occurring in its process of formation. Unlike most related research on museums, this study analyzed the process of image formation in an integrative path towards an analytic framework by integrating information sources, experience, and motivations, as well as location image halo effect, and the effect of image on satisfaction.

From an academic point of view, this work has attempted to provide a conceptual framework that supports continued progress in developing a better understanding of the process of image formation regarding museums. Given the limited empirical evidence on this topic to date, preliminary results seem to be helpful.

In this article, a general model has been developed and empirically validated so as to provide a more in-depth understanding of the museum image formation process and the relationship between the different dimensions of image, motivations, and information sources. Moreover, it has been empirically demonstrated that a museum's image may be influenced by the halo effect of the image of the place where it is located.

For practitioners, the findings of the exploratory survey provide evidence of the need for an overall image management program for museums in their destinations. 
Furthermore, the results help enhance museum managers' understanding of visitor image and its different components as well as of other external factors (including halo effect) that influence that image. In this regard, we believe that museums should be more concerned about location image and which features of the latter may be associated to museum image.

\section{References}

BALOGLU S., MCCLEARY K.W. (1999), "A Model of Destination Image Formation", Annals of Tourism Research, vol. 26, n. 1, pp. 868-897.

BALZER W.K., SULSKY L.M. (1992), "Halo and performance appraisal research: a critical examination", Journal of Applied Psychology, vol. 77, n. 6, 975-985.

BENNETT R., KOTTASZ R. (2000), "Practitioner perceptions of corporate reputation: an empirical investigation", Corporate Communications: an International Journal, vol. 5, n. 4, pp. 224-235.

BERNIER R. (2002), "The uses of virtual museums: The French viewpoint", paper presented at the Sixth international conference museums and the web 2002, MW2002, April 1720, Boston.

BILKEY W.J., NES E. (1982), "Country-of-Origin Effects on Product Evaluations", Journal of International Business Studies, vol. 13, n. 1, pp. 89-100.

BLACKETT T., BOAD B. (1999), Co-branding: The science of alliance, Macmillan, London.

CASCIO W.F. (1991), Applied psychology in personnel management, Englewood Cliffs, Prentice-Hall, New Jersey.

CATEORA P.R., GRAHAM J.L. (1999), International Marketing, 10th eEdition, Irwin McGraw-Hill, Boston, MA

CHON K.S. (1990), "The Role of Destination Image in Tourism: a Review and Discussion", Tourist Review, vol. 45, n. 2, pp. 2-9.

CONFETTO M.G., SIGLIOCCOLO M., TUCCILLO C. (2009), "Identifying key relations for destination competitiveness and for creating cultural tourism products: a value system approach to tourist destinations", Esperienze d'impresa, vol. 2, pp. 25-38.

COOPER W.H. (1981), "Ubiquitous halo", Psychological Bulletin, vol. 90, n. 2, pp. 218-244.

DIMAGGIO P.J. (1991), "Constructing an organizational field as a professional project: US art museums, 1920-1940", in Powell W.W., DiMaggio P.J. (eds.), The new institutionalism in organizational analysis, University of Chicago Press, Chicago.

DREDGE D., JENKINS J. (2003), "Destination place identity and regional tourism policy", Tourism Geographies, vol. 5, n. 4, pp. 383-407.

ECHTNER C.M., RITCHIE J.R.B. (1991), "The Meaning and Measurement of Destination Image", Journal of Tourism Studies, vol. 2, n. 2, pp. 2-12.

FELDMAN J.M. (1986), "A note on the statistical correction of halo error", Journal of Applied Psychology, vol. 71, n. 1, pp. 173-176.

FISHBEIN M., AJZEN I. (1975), Belief, Attitude, Intention and Behavior: An Introduction to Theory and Research, Addison-Wesley, Reading, MA.

FOMBRUN C.J., VAN RIEL C.B.M. (2004), Fame and Fortune: How Successful Companies Build Winning Reputations, Financial Times Prentice-Hall, Upper Saddle River, NJ.

GARTNER W.C. (1993), "Image Formation Process", Journal of Travel and Tourism Marketing, vol. 2, n. 3, pp. 191-215. 
GIL S.M., RITCHIE B.R.B. (2009), "Understanding the museum image formation process a comparison of residents and tourists", Journal of Travel Research, vol. 47, n. 4, pp. 480-493.

HAN M.C. (1989), “Country Image: Halo or Summary Construct?”, Journal of Marketing Research, vol. 26, n. 2, pp. 222-229.

HARRISON J. (1997), "Museums and Tourist Expectations", Annals of Tourism Research, vol. 24, n. 1, pp. 23-40.

HO R. (2006), Handbook of univariate and multivariate data analysis and interpretation with SPSS, CRC Press Boca Raton, FL.

HUBER J., MCCANN J.M. (1982), "The Impact of Inferential Beliefs on Product Evaluations", Journal of Marketing Research, vol. 19, August, pp. 324-33.

JANES R.R. (1997), Museums and the paradox of change: a case study in urgent adaptation, $2^{\text {nd }}$ ed., University of Calgary Press, Calgary.

JANES R.R. (1999), "Seven years of change and no end in sight: reflections from the Glenbow museum", International Journal of Arts Management, vol. 1, n. 2, pp. 4853.

JANSEN-VERBEKE M., VAN REKOM J. (1996), "Scanning Museum Visitors. Urban Tourism Marketing”, Annals of Tourism Research, vol. 23, n. 2, pp. 364-75.

JOHANSSON J.K., DOUGLAS S.P., NONAKA I. (1985), “Assessing the Impact of Country of Origin on Product Evaluation: A New Methodological Perspective", Journal of Marketing Research, vol. 22, n. 4, November, pp. 388-396.

KAWASHIMA N. (1999), "Knowing the Public: a Review of Museum Marketing Literature and Research", Museum Management and Curatorship, vol. 17, n. 1, pp. 21-39.

KIM Y., WEAVER P., MCCLEARY K. (1996), "A Structural Equation Model: The Relationship between Travel Motivation and Information Sources in the Senior Travel Market”, Journal of Vacation Marketing, vol. 3, n. 1, pp. 55-66.

KOTLER N., KOTLER P. (2001), "Can Museums Be All Things to All People? Missions, Goals, and Marketing Role", Museum Management and Curatorship, vol. 18, n. 3, pp. 271-287.

KUMAR P. (2005), "The impact of co-branding on customer evaluation of brand counter extension", Journal of Marketing, vol. 69, n. 7, pp. 1-18.

LI S., HUANG Z., ZHU J., CHAU P. (2002), "Cooperative advertising, game theory and manufacturer-retailer supply chains", Omega, vol. 30, n. 5, pp. 347-357.

LIU W.C., (2008), "Visitor Study and Operational Development of Museums", Museology Quarterly, vol. 22, n. 3, pp. 21-37.

MARRADI A. (2007), Metodologia delle scienze sociali, Il Mulino, Bologna.

NISBETT R.E., DECAMP WILSON T. (1977), "The Halo Effect: Evidence for Unconscious Alteration of Judgments", Journal of Personality and Social Psychology, vol. 35, n. 4, pp. 250-256.

PEARCE D.G. (1997), "Competitive Destination Analysis in Southeast Asia”, Journal of Travel Research, vol. 35, n. 4, pp. 16-24.

PHELPS A. (1986), "Holiday Destination Image-The Problem of Assessment: an Example Developed in Menorca", Tourism Management, vol. 7, n. 3, pp. 168-180.

PRENTICE R.C., GUERIN S., MCGUGAN S. (1998), "Visitor Learning at a Heritage Attraction: a Case Study of Discovery as a Media Product", Tourism Management, vol. 19, n. 1, pp. 5-23.

REKOM J.V. (1994), “Adding Psychological Value to Tourism Products", Journal of Travel and Tourism Marketing, vol. 3, n. 3, pp. 21-36. 
REUSSNER E. (2003), "Strategic management for visitor-oriented museums: A change of focus", International Journal of Cultural Policy, vol. 5, n. 1, pp. 95-108.

ROSENBERG.M.J., HOVLAND C.J., MCGUIRE W.J., ABELSON R.P., BREHM J.W. (1960), Attitude Organization and Change: An Analysis of Consistency Among Attitude Components, Yale University Press, New Haven.

RUSSELL J.A., SNODGRASS J. (1987), "Emotion and Environment", in Stockols D., Altman I. (eds.), Handbook of Environmental Psychology, John Wiley, New York.

SAAL R.E., DOWNEY R.G., LAHEY M.A. (1980), "Rating the ratings: Assessing the psychometric quality of rating data", Psychological Bulletin, vol. 88, n. 2, pp. 413428 .

SHAWN C. (2000), The co-marketing solution, NTC Business Books, Chicago.

SIANO A., CONFETTO M.G., VOLLERO A. (2008), "Governance-struttura-sistema: un modello di management della comunicazione per il marketing territoriale", 7th International Congress "Marketing Trends", Venezia, Gennaio 25-26.

SIANO A., CONFETTO M.G., SIGLIOCCOLO M. (2009), "Destination reputation management and leverage points. Rethinking cultural marketing for weak areas", 8th International Marketing Trends Congress, Paris, January 16-17, 2009.

SIANO A., EAGLE L., CONFETTO M.G., SIGLIOCCOLO M. (2010), "Destination competitiveness and museum marketing strategies: an emerging issue in the Italian context", Museum management and curatorship, vol. 25, n. 3, pp. 259-276.

SIANO A., SIGLIOCCOLO M. (2008), "Cultural goods and place reputation: a cross analysis on Italian museums", The International Journal of Knowledge, Culture and Change Management, vol. 8, n. 9, pp. 1-11.

SIGLIOCCOLO M., EAGLE L., KITCHEN P., CONFETTO M.G. (2009), "Exploring the link between managing cultural heritage and tourism industry competitiveness: a two country comparison", Esperienze d'impresa, vol. 2, pp. 25-38.

SOLIMA L. (1999), "I visitatori dei musei: un confronto internazionale", in AA. VV., Atti del XXI Convegno AIDEA La gestione e la valorizzazione dei beni artistici e culturali nella prospettiva aziendale, Siena, October 30-31.

STERN E., KRAKOVER S. (1993), "The Formation of a Composite Urban Image", Geographical Analysis, vol. 25, n. 2, pp. 130-146.

THOMAS R., LONG, J. (2000), "Improving competitiveness. Critical success factors for tourism development", Local Economy, vol. 14, n. 4, pp. 313-328.

THORNDIKE E.L. (1920), "A Consistent Error in Psychological Ratings", Journal of Applied Psychology, vol. 4, pp. 25-29.

THYNE M. (2001), "The Importance of Values Research for Nonprofit Organisations: the Motivation-Based Values of Museum Visitors", International Journal of Nonprofit and Voluntary Sector Marketing, vol. 6, n. 2, pp. 116-130.

TOMAS S.R., CROMPTON J.L., SCOTT D. (2003), "Assessing Service Quality and Benefits Sought Among Zoological Park Visitors", Journal of Park and Recreation Administration, vol. 21, n. 2, pp. 105-124.

UM S., CROMPTON J.L. (1992), "The Roles of Perceived Inhibitors and Facilitators in Pleasure Travel Destination Decisions”, Journal of Travel Research, vol. 30, n. 3, pp. $18-25$

VAUGHAN R. (2001), "Images of a Museum", Museum Management and Curatorship, vol. 19 , n. 3, pp. 253-268.

WEIL W.E. (2000), "Transformed from a cemetery of bric-a-brac", in Sheppard B. (ed.), Perspectives on Outcome Based Evaluation for Libraries and Museums, Institute of Museum and Library Services, Washington. 
WELLS F.L. (1907), “A statistical study of literary merit”, Archives of Psychology, vol. 1, n. 7, pp. 5-30.

YUCELT U. (2000), "Marketing museums: An empirical investigation among museum visitors", Journal of Nonprofit\& Public Sector Marketing, vol. 8, n. 3, pp. 3-13.

YUE J., AUSTIN J., WANG M., HUANG Z. (2006), "Coordination of cooperative adverting in a two-level supply chain when manufacturer offers discount", European Journal of Operational Research, vol. 168, n. 1, pp. 65-85. 
